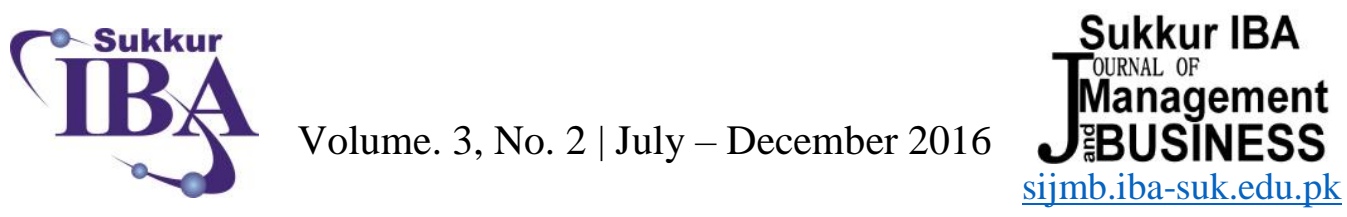

\title{
Determinants of Organizational Performance: A Case of Punjab Police
}

\author{
Hood Laeeq ${ }^{1 *}$ \\ Othman Yeop Abdullah Graduate School of Business, Universiti Utara Malaysia \\ Arfan Shahzad \\ Othman Yeop Abdullah Graduate School of Business, Universiti Utara Malaysia \\ Subramaniam Sri Ramalu \\ Othman Yeop Abdullah Graduate School of Business, Universiti Utara Malaysia \\ Muhammad Fareed \\ School of Business and Management, Universiti Utara Malaysia
}

\begin{abstract}
:
In the last three decades, the security issues have been raised in the state of the Punjab (Pakistan) which ultimately leads to the breakdown of the country's economy. However, the purpose of this paper is to determine the effect of the political interference on the performance of Punjab police (Pakistan) with the moderating role of organizational support. To elicit the findings, a total of 159 survey questionnaires were compiled from station house officers (SHOs) of Punjab police (Pakistan). Furthermore, this study has applied PLS-SEM technique to analyze the data. The findings reveal that a negatively significant effect of political interference on the performance of Punjab police (Pakistan). Moreover, the findings also showed the significant moderating effect of organizational support in the instance of political interference.
\end{abstract}

Keywords: Pakistan Organizational Performance, Political Interference, Organizational Support, Punjab Police, Pakistan, PLS-SEM.

\section{Introduction}

Since the last two decades, state governments are more concerned about enhancing the performance of public organizations McBride (2008). Furthermore, government institutions around the world are searching for improving their performance in terms of program outcomes, use of public resources, citizen participation, and customer satisfaction, strengthen integrity, transparency, combat and prevent corruption, and

https://doi.org/10.30537/sijmb.v3i2.98

1 hood.laeeq@hotmail.com

${ }^{*}$ Corresponding Author

SIJMB | E-ISSN: 2410-1885; P-ISSN: 2313-1217 @ 2016 Sukkur Institute of Business Administration - All rights reserved 
accountability Ashour (2004). These reforms are important and crucial to enhance the performance of public organizations, protecting public performance, and strengthen the government's role in providing basic services and development. In addition to this, Ashour (2004) also pointed out that such reforms in the public organizations need to enhance its effectiveness and efficiency. To continue this, one of the foremost public department is the law enforcement agency that helps to retain the law and order situation in the society and provide a peaceful safety environment to the citizens. To create a good relation and to maintain the confidence level is the major duty of the police that links an ordinary citizen with the organization Bouffard and Piquero (2010).

Pakistan is the 6th largest country of the world in terms of population Ministry of Finance (2012). In addition to that, Punjab being a leading populous province (60\% of the country) should contribute greatly in the economy of the country, especially since the most important and historic foreign direct investment (FDI) of 46 billion US dollars has just taken place in the shape of China-Pakistan Economic Corridor (CPEC) which is expected to further strengthen trade and economic cooperation between the two countries Tiezzi (2014). However, the unprecedented law and order situation in the country in general and Punjab in specific, the country's economy is sluggish Jabbar and Mohsin (2014). Ideally, in a modern state, it is important for state's police or law enforcement agencies to perform better and reduce crime rates. Therefore, state authorities must recognize the crime issues and security concerns to provide friendly environment to foreign investor for boosting the economy of the country by inviting foreign investments in the largest province of Pakistan. In fact, this specific area has received less attention by academics and it is perceived that political interference is one of the main reason of poor performance of Punjab police (United States Institute of Peace, 2011). Moreover, due to lack of organizational support, political interference escalates in the police department. In addition to this the report published by the United States Institute of Peace as cited above, mentioned that different political parties and politicians influence the police department significantly. Majority of the higher posts in Police department, has been politicized by the political elites. For the last one decade, most of the officers have been placed in different areas based on the political connections. The situation of crime rate is more than worst, as stated in the cited report.

It is important to note here that there are other factors that may be affecting the organizational performance, however, in this specific case of police department of Punjab, where the political interference surpasses every other factor resulting in nonfunctionality of the police department with respect to implementing the law.

With this in mind, this study is to examine the effect of political interference on the performance of Punjab police (Pakistan) with the moderating role of organizational support, with the presumption that this political interference brings every other factor to a static position, where its performance impact seems to be spurious or deemed impossible to judge.

Sukkur IBA Journal of Management and Business | Volume 3 No. 2 July - December 2016 ○ Sukkur Institute of Business Administration 


\section{Review of Literature}

2.1. Organizational Performance

Organizational performance is defined as a measure of how an organization is managed well and how an organization can deliver the value to their customers and stakeholders Moullin (2007). Moreover, Antony and Antony and Bhattacharyya (2010) defined organizational performance as the tool and measurement that is used to assess and evaluate the organization's success to create and deliver value to its internal and external customers. Moreover, organizational performance facilitates an organization to make some pre-determined strategy for making profit and increasing market share, high performance and productivity Koontz and Donnell (1993) In regard of this, earlier researchers have studied that the organizational performance basically based on the business performance Richard, Wu, and Chadwick (2009). Conversely, organizational performance can be measured through six dimensions, which are; efficiency, effectiveness, innovation, quality, productivity and profitability Sink and Tuttle (1989). A positive police image is necessary for the police to work effectively, as the police rely on citizens' cooperation in reporting crimes or providing information (Bouffard and Piquero (2010); Yuksel and Tepe (2013)).

\subsection{Political Interference}

In the field of management, very few studies have been conducted to examine the relationship between political interference and performance in the public sector Usang and Salim (2015). While, this subject matter remains a thoughtful challenge to both administrative practitioners and politicians in government. The previous research has suggested that the local politicians influence the criminal justice systems outcomes generally and specifically Stucky (2005). Likewise, in the background of Punjab police, politicians badly effect police performance, because they influence the duties and decisions of Punjab police (United States Institute of Peace, 2011). Furthermore, the researchers have confirmed that the police executives claimed that politicians intervene in the departmental decisions Koper, Maguire, Moore, and Huffer (2001). However, the department is not empowered to take any decision freely and working as an autonomous body and that is one of the reason of declining the performance.

According to the earliest researcher, Fyfe, Greene, Walsh, Wilson, and McLaren (1997) has demonstrated that police organization is influenced severely by the variation across local political systems. In the support of the above argument, various researchers depicted that politicians affect the justice system as a violence (Jacobs (1998); Stucky (2003)). Some scholars have argued that interference of higher government is important for policy direction, while others view it purely on self-interest of higher government (Chang and Wong (2002); Shleifer and Vishny (1994)). Political interference refers to influences applied by higher authorities of government or political leaders on the administration of public institutions. Although, the basic responsibility of every state's government is to perform a supervisory role in proper functioning of the local governments, but their influences have become overwhelming Asaju, (2010).

Sukkur IBA Journal of Management and Business | Volume 3 No. 2 July - December 2016 @ Sukkur Institute of Business Administration 


\subsection{Organizational Support}

Organizational support has been considered as the moderating variable in the present study. One of the vital feature that has been widely discussed to affect employees' performance is organizational support such as resources (IT, Financial and Human), infrastructure, social and moral support Mathis and Jackson (2004). In addition, as it is said earlier, employees' performance lead to organizational performance, therefore, organizational support is a significant factor to enhance organizational performance. The notion behind is that employees may not be effective in performing their roles if they lack adequate skills, latest technology, financial resources and empowerment from the top management. Employees' performance is primarily a consequence of organizational support as it permits employees to utilize their competencies effectively. Organizational support may not only augment employees' motivation to take their job seriously, but it might also enhance the employees' willingness to perform better Lin and Lin (2011). According to Mathis and Jackson (2004) numerous factors influence on employees' performance comprising their abilities, efforts expended and the organizational support they receive. Kane, Crawford, and Grant (1999) found that employees' effectiveness can be attained by organizational support. While, Black, Jensen, and Gregersen (2003) argued that it is very difficult for employees to get adequate support from the organization due to the lack of financial investments in this particular area. Whereas, Sharif and Ahmad (2009) have originated that organizational support has some moderating role in the studies of behavioural variables in organizations. Consequently, organizational support is expected to moderate the relationship of political interference with organizational. According to Bouranta, Siskos and Tsotsolas (2015) suggested in their study that employee should be encouraged to learn new skills and department should keep updating their employees with new changing infrastructure. Another duty of the police department is to empower their officials, though they can freely take their decisions. Moreover, top management support is vital for the subordinate officers that empowers them to make decisions independently and according. However, the influence from political parties retrain the police department from top level to the bottom, hence jeopardize the important role of police in the law implementation.

\section{Research Framework}

The research model shown in figure 1 exhibits the predictor variable i.e., political interference that predicts organizational performance through moderating role of organizational support. 


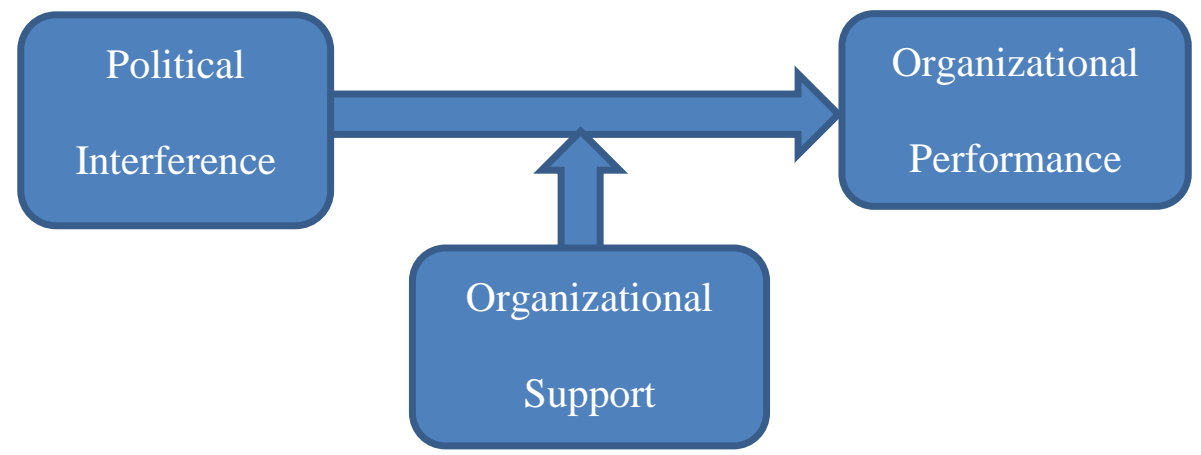

Figure: 1 - Research Model for Present Study

Based on the above research model the following hypotheses are anticipated.

H1: Political interference is significantly related to organizational performance as perceived by personnel of Punjab police.

H2: Organizational support moderates the relationship between political interference and organizational performance as perceived by personnel of Punjab police.

\section{Data and Methodology}

The survey instrument for the present study is adapted from the prior researches (Kaplan and Norton (2005); Newman, Thanacoody, and Hui (2011); Sharif and Ahmad (2009)) using five point Likert scale and it is modified through proper alteration that is appropriate for the context of Punjab police (Pakistan). The data was collected through survey questionnaire; however, 234 questionnaires were distributed to the station house officers (SHOs) of the Punjab police, out of which 159 questionnaires were received which makes $68 \%$ response rate. The sample size of the current study was established grounded on the benchmark specified by Krejcie and Morgan (1970). Nonetheless, the present study has employed the simple random sampling technique for efficient data collection since SHOs are extremely busy to fulfill their duties and responsibilities. In addition, before sending the survey questionnaire for actual data collection a pilot study has been conducted with 30 SHOs to confirm the reliability and validity of the instrument using Cronbach's alpha Gardner Gardner (1995). The alpha values of all the variables are above 0.70 which shows that all the constructs are reliable and they should be retained in the study. Moreover, assessment of the measurement model, more specifically, convergent validity and internal consistency have been tested using SmartPLS3 through assessing the values of Average Variance Extracted (AVE) and Composite Reliability (CR) grounded on the criteria specified by scholars (F. Hair Jr, Sarstedt, Hopkins, and G. Kuppelwieser (2014); Fornell and Larcker (1981)). Conferring to Hair, Anderson, Babin, and Black (2010) it is inevitable that latent constructs should explain a minimum half of the variance (AVE > 0.50) in the indicators. The values of AVE and CR for latent constructs have met and surpassed the lowest threshold value suggested by above mentioned scholars. However, all the constructs are valid and reliable, therefore they have been retained for further analyses.

Sukkur IBA Journal of Management and Business | Volume 3 No. 2 July - December 2016 ○ Sukkur Institute of Business Administration 
The values of AVE and CR are stated underneath in the Table 1.

Table 1: Factor Loadings, Cronbach's alpha, Composite Reliability, AVE

\begin{tabular}{llrlll}
\hline \multicolumn{1}{c}{ Variables } & Items & $\underline{\text { Loadings }}$ & $\underline{\text { Alpha }}$ & $\underline{\text { CR }}$ & AVE \\
\hline Organizational & & & & & \\
Performance & OP2 & 0.812 & 0.862 & 0.893 & 0.511 \\
& OP3 & 0.643 & & & \\
& OP4 & 0.724 & & & \\
& OP5 & 0.688 & & & \\
& OP7 & 0.669 & & & \\
& OP8 & 0.643 & & & \\
Organizational Support & OP9 & 0.722 & & & \\
& OP10 & 0.799 & & & \\
& OS2 & 0.615 & 0.772 & 0.844 & \\
& OS3 & 0.712 & & & \\
& OS4 & 0.732 & & & \\
Political Interference & OS5 & 0.752 & & & \\
& OS6 & 0.787 & & & \\
& PI1 & 0.952 & 0.949 & 0.967 & 0.906 \\
& PI2 & 0.97 & & & \\
\hline
\end{tabular}

Additionally, discriminant validity has also been calculated, which explains fundamentally how indicators are representing the latent constructs, moreover, how much they are different from other constructs Fornell and Larcker (1981). The fundamental argument is that the square root of AVE value for any specific construct must be greater than the relationship of that construct with other constructs in the model F. Hair Jr et al. (2014). The results of discriminant validity have presented below.

Table 2: Discriminant Validity

\begin{tabular}{cccc}
\hline Variables & $\underline{\mathrm{OP}}$ & $\underline{\mathrm{OS}}$ & $\underline{\mathrm{PI}}$ \\
\hline OP & 0.715 & & \\
OS & 0.698 & 0.722 & 0.952 \\
PI & -0.289 & -0.201 & \\
\hline
\end{tabular}

\section{Finding and Discussion}

The next step is an estimation of structural model for testing direct and moderating hypotheses. The structural model has been measured using SmartPLS3 by performing bootstrapping. The results of direct and moderating hypotheses are presented in Table 3.

Sukkur IBA Journal of Management and Business | Volume 3 No. 2 July - December 2016 @ Sukkur Institute of Business Administration 
Table 3: Hypotheses Testing

\begin{tabular}{|c|c|c|c|c|}
\hline Paths & $\begin{array}{l}\text { Path } \\
\text { coefficients }\end{array}$ & $\frac{\text { Standard }}{\text { Deviation }}$ & $\frac{\mathrm{T}-}{\text { Statistics }}$ & $\frac{\mathrm{P}-}{\text { Value }}$ \\
\hline $\mathrm{PI}->\mathrm{OP}$ & -0.155 & 0.055 & 2.821 & 0.002 \\
\hline $\begin{array}{l}\text { PI*OS- } \\
>\mathrm{OP}\end{array}$ & 0.111 & 0.056 & 1.964 & 0.025 \\
\hline
\end{tabular}

Table 3 presents the results of both direct and moderating hypotheses. Findings reveal that both hypotheses are significant. In direct relationship, political interference has the negative significant impact on the organizational performance at $p<0.002$ level of significance $(\beta=-0.155, \mathrm{t}=2.821, \mathrm{p}=0.002)$. While moderating hypothesis is significant at $\mathrm{p}<0.025(\beta=0.111, \mathrm{t}=1.964, \mathrm{p}=0.025)$. Therefore, it is concluded that both hypotheses are accepted.

The results of the study demonstrate that the reason behind the poor performance of Punjab police is the interference by the politicians in the tasks, duties, and responsibilities of SHOs.

The findings of the study explain that Punjab police department is significantly influenced by the political system of Pakistan. These findings are in line with the findings of Noe and Wilk (1993), who contended that political interference in the management of an organization could be harmful for the organizational performance. Findings are not surprised as some of the leading political parties who are currently representing opposition are consistently highlighting the issue of interference of higher political authorities in the responsibilities of Punjab police (United States Institute of Peace, 2011). The Punjab police department is victimized by the politician and local political parties, which ultimately is ruining their credibility and their performance consistently declining. Similarly, a study on the local government administration of Nigeria resulted that political interference affects negatively on the performance Dang (2015) which also justifies the negative findings of the current study. In addition to this, the opinion of the study that, under normal situations politics and administration are two sides of the same coin. Politics is about making policies while the policies are implemented by the administrators. Whereas, the administrators provide advice to the politicians in the formulation of policies, it was observed that politicians interrupt and restrict in the affairs of the local government administrators.

\section{Implication of the Study}

In the current study, many insights concerning the issues related to the organizational performance of Punjab police (Pakistan) have been arisen. The current study, as to date, is one of very few studies conducted in the Pakistan and especially in the security sector to examine the effect of political interference with the moderating role of organizational support. Previous studies also demonstrated that in the field of management, very few

Sukkur IBA Journal of Management and Business | Volume 3 No. 2 July - December 2016 @ Sukkur Institute of Business Administration 
studies have been conducted to examine the relationship between political interference and performance in the public sector Usang and Salim (2015). While, the topic political interference remains a thoughtful challenge to both Administrative practitioners and politicians in government, while the history of the debate is well documented. Whereas, in the present study political interference is the main contribution of the study, especially in the Punjab police department. Because nobody has tested it before in the context of Pakistan.

Furthermore, this study is an effort to enlarge the boundary of the existing knowledge in the literature by examining the moderating effect of organizational support on the organizational performance using the sampling technique of PLS-SEM 3. Ultimately, this research can be used as a base for creating certain rules and policies of the Pakistan Government in practicing and applying a model of this study to enhance the development, growth, and performance of their service organizations. This study can increase the awareness of Punjab police (Pakistan) higher authorities about what capabilities and competencies they have, that can help for more development and improvement. The police department must be an independent body within the certain limits, though they can improve themselves in a better way. There should be no interference in the departmental decision, every cadre must have the right to perform their duty at their level.

\section{Conclusion}

The aim of the present study was to explain the effect of political interference on the organizational performance of Punjab police (Pakistan). Moreover, the study aimed to test the moderating effect of organizational support in the relationship between political interference and organizational performance. Empirical findings of the study have shown the negative significant effect of political interference on the performance of Punjab police. Similarly, the findings also revealed the importance of organizational support to enhance organizational performance. In addition to that, the results highlighted the prominence of the moderating role of organizational support for improving organizational performance. It is believed that Punjab police is vital law enforcement agency in Pakistan, which is responsible to provide security to the community. However, it was important to scrutinize the performance of Punjab police (Pakistan). Therefore, this study has contributed in enlightening the factors which contribute to their performance, such as; political interference and organizational support.

Future scholars who intend to carry out their research in the context of security agencies in Pakistan or more specifically in the context of Punjab police should ponder on adding other variables which can enhance organizational performance. Particularly, in the time when many foreign investors are looking for investment opportunities in Pakistan, security is the basic feature which they always look for, however, performance of these security agencies should be on higher side. Additionally, upcoming researchers might

Sukkur IBA Journal of Management and Business | Volume 3 No. 2 July - December 2016 @ Sukkur Institute of Business Administration 
consider qualitative study to explore the phenomenon more comprehensively by interviewing the higher authorities of security agencies. By doing that researchers may get into clearer understanding how security agencies can be more effective in fulfilling their duties and responsibilities. The scope of the study might also be enhanced by future research studies to other provinces of Pakistan for the purpose of better security condition for whole the country (Pakistan).

\section{References}

Antony, J. P., \& Bhattacharyya, S. (2010). Measuring organizational performance and organizational excellence of SMEs-Part 1: a conceptual framework. Measuring Business Excellence, 14(2), 3-11.

Ashour, A. (2004). Integrity, Transparency and Accountability in Public Sector Human Resources Management. Alexandria University, Egypt.

Black, M., Jensen, R. J., \& Gregersen, H. B. (2003). Seeing the elephant: Human resource management challenges in the age of globalization. STRATEGIC HUMAN RESOURCE MANAGEMENT, 410.

Bouffard, L. A., \& Piquero, N. L. (2010). Defiance theory and life course explanations of persistent offending. Crime \& Delinquency, 56(2), 227-252.

Chang, E. C., \& Wong, S. M. (2002). Corporate Governance, Political Interference, and Corporate Performance of China's Listed Companies. The University of Hong Kong, Working paper.

Dang, M. E. (2015). The impact of political interference on Local Government Administration in Nigeria: Experience from Plateau State. Paper presented at the Proceedings of International Academic Conferences.

F. Hair Jr, J., Sarstedt, M., Hopkins, L., \& G. Kuppelwieser, V. (2014). Partial least squares structural equation modeling (PLS-SEM) An emerging tool in business research. European Business Review, 26(2), 106-121.

Fornell, C., \& Larcker, D. F. (1981). Structural equation models with unobservable variables and measurement error: Algebra and statistics. Journal of marketing research, 382-388.

Fyfe, J. J., Greene, J. R., Walsh, W. F., Wilson, O. W., \& McLaren, R. C. (1997). Police administration: McGraw-Hill New York.

Gardner, P. L. (1995). Measuring attitudes to science: Unidimensionality and internal consistency revisited. Research in science education, 25(3), 283-289.

Hair, J. F., Anderson, R. E., Babin, B. J., \& Black, W. C. (2010). Multivariate data analysis: A global perspective (Vol. 7): Pearson Upper Saddle River, NJ.

Jabbar, M., \& Mohsin, H. (2014). Does Police Strength and Conviction Help to Deter Violent. International Journal of Economics and Empirical Research, 2, 2-52.

Jacobs, D. (1998). The Determinants of Deadly Force: A Structural Analysis of Police Violence 1. American Journal of Sociology, 103(4), 837-862.

Kane, B., Crawford, J., \& Grant, D. (1999). Barriers to effective HRM. International Journal of Manpower, 20(8), 494-516.

Sukkur IBA Journal of Management and Business | Volume 3 No. 2 July - December 2016 ๑ Sukkur Institute of Business Administration 
Kaplan, R. S., \& Norton, D. P. (2005). The balanced scorecard: measures that drive performance. Harvard business review, 83(7), 172.

Koontz, H., \& Donnell, C. (1993). Introduction to Management: McGraw-Hill Inc., New York.

Koper, C. S., Maguire, E. R., Moore, G. E., \& Huffer, D. E. (2001). Hiring and retention issues in police agencies: Readings on the determinants of police strength, hiring and retention of officers, and the federal COPS program: Urban Institute Washington, DC.

Krejcie, R. V., \& Morgan, D. W. (1970). Determining sample size for research activities. Educational and psychological measurement, 30(3), 607-610.

Lin, J. S.-J., \& Lin, S.-C. (2011). Moderating effect of organizational climate on the relationship of organizational support and service-oriented organizational citizenship behaviors. African Journal of Business Management, 5(2), 582.

Mathis, R. L., \& Jackson, J. H. (2004). Human Resource Management. International Student Edition. South-Western, a division of Thomson Learning, Thomson Learning is a trademark used herein under license: Singapore.

McBride, H. M. (2008). Parkin mitochondria in the autophagosome. The Journal of cell biology, 183(5), 757-759.

Ministry of Finance, G. o. P. (2012). PAKISTAN ECONOMIC SURVEY 2011-12

Moullin, M. (2007). Performance measurement definitions: Linking performance measurement and organisational excellence. International journal of health care quality assurance, 20(3), 181-183.

Newman, A., Thanacoody, R., \& Hui, W. (2011). The impact of employee perceptions of training on organizational commitment and turnover intentions: a study of multinationals in the Chinese service sector. The International Journal of Human Resource Management, 22(8), 1765-1787.

Noe, R. A., \& Wilk, S. L. (1993). Investigation of the factors that influence employees' participation in development activities. Journal of applied psychology, 78(2), 291.

Richard, O. C., Wu, P., \& Chadwick, K. (2009). The impact of entrepreneurial orientation on firm performance: the role of CEO position tenure and industry tenure. The International Journal of Human Resource Management, 20(5), 1078-1095.

Sharif, M. Y., \& Ahmad, A. (2009). HR Professionals' Effectiveness in a KnowledgeBased Organization: A Malaysian Case. The International Journal of Knowledge Culture \& Change Management, 8(12), 13-28.

Shleifer, A., \& Vishny, R. W. (1994). Politicians and firms. The Quarterly Journal of Economics, 109(4), 995-1025.

Sink, D. S., \& Tuttle, T. C. (1989). Planning and measurement in your organization of the future: Industrial Engineering And Management.

Stucky, T. D. (2003). Local politics and violent crime in US cities. Criminology, 41(4), $1101-1136$.

Stucky, T. D. (2005). Local politics and police strength. Justice Quarterly, 22(2), 139169.

Sukkur IBA Journal of Management and Business | Volume 3 No. 2 July - December 2016 ○ Sukkur Institute of Business Administration 
Tiezzi, S. (2014). China, Pakistan flesh out new 'economic corridor'. The Diplomat, 20. Usang, O. U. E., \& Salim, B. (2015). A conceptual perspective of internal audit quality and local government performance in Nigeria.

Yuksel, Y., \& Tepe, F. (2013). Citizen satisfaction with police and community policing. European scientific journal, 9(14). 